\title{
Transplantace srdce
}

\author{
Lenka Špinarová', Jindřich Špinar², Jiří Vítovec ${ }^{1}$ \\ 1\%. interní kardio-angiologická klinika LF MU a FN u sv. Anny v Brně \\ 'Interní kardiologická klinika LF MU a FN Brno, pracoviště Bohunice
}

\section{Souhrn}

Je podán přehled o historii, indikacích a sledování po transplantaci srdce, včetně využití mechanických podpor. Jsou zmíněny možné komplikace v potransplantačním sledování, jako je rejekce, infekce, vaskulopatie štěpu, metabolické komplikace, hypertenze či malignity. Je shrnuta farmakoterapie, která se užívá zejména k potlačování imunitní odpovědi organizmu. Transplantace srdce zlepšuje prognózu pacientů se srdečním selháním a rovněž kvalitu života.

Klíčová slova: imunosuprese - mechanické srdeční podpory - rejekce - terminální srdeční selhání - transplantace srdce

\section{The heart transplantation}

\section{Summary}

The article reviews history, indication and follow-up after heart transplantation, including the mechanical assist devices. Various complications of posttransplant follow-up are mentioned, e.g. rejection, infection, vasculopathy, metabolic disorders, hypertension or malignities. Pharmacotherapy used for immunosuppression is discussed. Heart transplantation improves the prognosis of patients with previous heart failure and also their quality of life.

Key words: heart transplantation - immunosuppression - mechanical assist devices - rejection - terminal heart failure

\section{Historie}

Srdeční transplantace je nyní již běžně klinicky užívanou metodou léčby pacientů s těžkým srdečním selháním.

$\checkmark$ roce 2017 uplynulo 50 let od první transplantace srdce, kterou provedl 3. 12. 1967 Christian Barnard v Kapském Městě v Jihoafrické republice. Přijemcem byl 54letý L. Washkanski, který zemřel 18 . den po operaci na bronchopneumonii [1].

V pořadí druhý pacient, 58letý stomatolog P. Blaiberg žil 18 měsíců. Zemřel na do té doby neznámou komplikaci: vaskulopatii štěpu. Zajímavé bylo, že C. Barnard ignoroval tvrdé rasistické zákony v JAR a bělochovi transplantoval srdce míšence [2].

První transplantace srdce $v$ Evropě byla provedena dr. Christianem Cabrolem 27. 4. 1968 v Pařǐzi, ve Francii. Rok 2018 tak znamenal zlaté jubileum v oblasti transplantace pro Evropu [3].

První transplantaci srdce $v$ tehdejším Československu provedl 9. 7. 1968 tým akademika K. Šišky. Pacientka po 6 hod zemřela [4]. V začátcích transplantací srdce to nebylo nic neobvyklého, protože pacienti umírali při nedokonalé imunosupresi na akutní rejekce. Tato skutečnost byla také důvodem $\mathrm{k}$ útlumu transplantací na celém světě $a k$ jejich novému vzestupu $v 80$. letech
20. století, kdy byl do rutinní imunosupresivní léčby zaveden cyklosporin $A$ a přežívání pacientů po srdeční transplantaci se rapidně zlepšilo. $V 60$. letech minulého století bylo jednoleté přežívání po srdeční transplantaci pouze okolo $25 \%$.

V současnosti je jednoleté přežívání pacientů po srdeční transplantaci u pacientů s primární diagnózou dilatační kardiomyopatie $84 \%$, u ischemiků $81,5 \%$ a u pacientů se srdeční vadou $77 \%$. Pětileté přežívání je 71 \% a desetileté $56 \%$ [5]. První transplantace srdce v České republice byla provedena v IKEM Praha v roce 1984 [6].

Druhé transplantační centrum v České republice zahájilo svou činnost v roce 1992 v Brně v Centru kardiovaskulární a transplantační chirurgie pod tehdejším vedením prof. MUDr. Jana Černého, CSc.

\section{Indikace}

Vybrat vhodného pacienta k provedení srdeční transplantace a zvolit vhodný okamžik výkonu je velmi komplexní a složité rozhodování. Pacient musí splňovat jednak indikační kritéria, tj. prokázat, že jeho kardiální stav je natolik závažný a neexistuje jiný způsob léčby tohoto stavu, na druhé straně nesmí mít nemocný kontraindikace, které by limitovaly jeho další přežívání po výkonu. Je samozřej- 
mostí, že pacient musí mít plnou léčbu chronického srdečního selhání.

Tato léčba zahrnuje titraci blokátorů angiotenzin konvertujícího enzymu (ACEI) a betablokátorů do maximálních tolerovaných dávek, diuretika a blokátory mineralokortikoidních receptorů. $V$ prípadě stále trvajících symptomů je možnost vyměnit $A C E l$ za sakubitril-valsartan. U pacientů, kteří splňují indikaci, by měla být zavedena také resynchronizační terapie $[7,8]$.

Mezi objektivní posouzení tíže srdečního selhání patří spiroergometrie: hodnoty $\mathrm{pVO}_{2} \leq 12 \mathrm{ml} / \mathrm{kg} / \mathrm{min}$ při užívání betablokátorů nebo $\leq 14 \mathrm{ml} / \mathrm{kg} / \mathrm{min}$ při jejich intoleranci představují potenciální indikaci k transplantaci srdce. K hodnocení validity testu je potřeba, aby respirační kvocient byl > 1,05. Další parametry získané ze zátěžového testu, které jsou důležité pro rozhodování je u žen, a u osob $<50$ let, $\mathrm{pVO}_{2} \leq 50 \%$ a Ve/ $\mathrm{VCO}_{2}$ slope $>35$ [9].

Indikace a kontraindikace srdeční transplantace jsou uvedeny v tab. 1.

U pacientů, kteří mají zvýšenou plicní hypertenzi, pokud je navzdory farmakologickému testování plicní vaskulární rezistence $>3,5 \mathrm{~W} \mathrm{j}$., je možné zvážit implantaci levostranné srdeční podpory (left ventricular assist device - LVAD). Rovněž pacienti, kteří se klinicky horší a nemuseli by se transplantace srdce dožít, mají naději v implantaci LVAD. Předpokladem indikace LVAD je dobrá spolupráce s pacientem, sociální zázemí a přijatelná funkce pravé komory srdeční.

Indikace LVAD dle doporučení Evropské kardiologické společnosti z roku 2016 ukazuje tab. 2 [7]. Mezi kontraindikace patří: nízký tělesný povrch, anatomické problémy (mechanická aortální či mitrální chlopeň), dysfunkce pravé komory, restriktivní kardiomyopatie, významné komorové arytmie, koagulopatie, sociální důvody či hemodialýza [10].

\section{Potransplantační sledování}

Vlastní operací léčba pacienta nekončí, ale naopak začíná pečlivé potransplantační sledování. $V$ průběhu operace je nahrazeno srdce príjemce srdcem dárce, a to tak, že příjemce má od dárce celý srdeční sval, včetně koronárních cév.

\section{Imunosupresivní léčba}

Aby se srdce neodhojilo (nedošlo k rejekci), musí pacient trvale užívat léky na oslabení imunity, tzv. imunosupresiva, která podáváme v kombinaci, abychom zachytili proces rejekce na různých úrovních. Imunosupresiva se mohou v játrech metabolizovat stejnou cestou jako řada dalších léků (antibiotika, léky na léčbu hypertenze, žaludečních vředů aj) a může docházet k ovlivnění jejich hladin, a tím i účinnosti.

\section{Tab. 1. Indikace a kontraindikace transplantace srdce. Upraveno podle [9]}

\begin{tabular}{|l|l}
\hline indikace & motivovaný, emočně stabilní a dobře informovaný pacient \\
\hline pacient schopný dodržovat intenzivní léčbu po operaci (kompliantní) \\
\hline aktivní infekce \\
těžká periferní nebo centrální ateroskleróza \\
\hline farmakologicky neovlivnitelná plicní hypertenze (může být zvážen LVAD s následným přehodnocením stavu) \\
\hline malignita (spolupráce s onkologem na posouzení rizika rekurence) \\
\hline ireverzibilní ledvinné poškození (GF < 30 ml/min) \\
\hline systémové onemocnění s multiorgánovým postižením \\
\hline kiné závažné komorbidity se špatnou prognózou \\
\hline předtransplantační BMI > 35 kg/m² \\
\hline současné uživání alkoholu nebo drog \\
pacient, který nemá dostatečné sociální zázemí, aby dosáhl kompliance s léčbou
\end{tabular}

\section{Tab. 2. Indikace LVAD. Upraveno podle [7]}

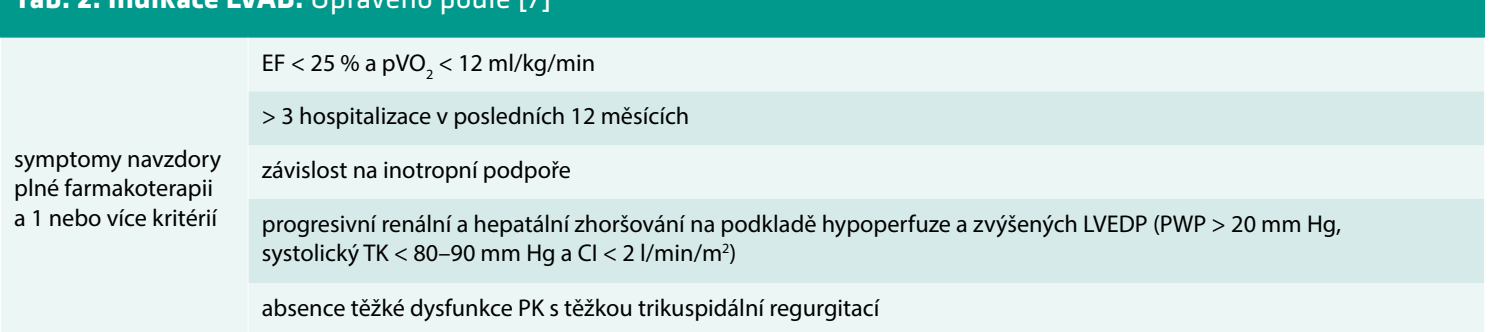




\section{Základní skupiny imunosupresiv}

- inhibitory kalcineurinu (CNI): cyklosporin a takrolimus

- mTOR inhibitory (everolimus a sirolimus)

- antiproliferativní látky: mykofenolát mofetil a azatioprin

- kortikoidy (prednison)

Základním lékem, který významně zlepšil přežívání pacientů po transplantaci, byl cyklosporin, který společně s azatioprinem tvořil klasickou imunosupresi v 80 . a 90 . letech 20. století. V 1. roce byla tato dvojkombinace doplněna i kortikoidy. Nynější léčebná schémata nahradila azatioprin mykofenolátem mofetilem. Místo cyklosporinu se používá novější kalcineurinový inhibitor - takrolimus. Ve speciálních případech mohou být do léčby zavedeny mTOR (mammalian target of rapamycin) inhibitory (everolimus či sirolimus), at' již v kombinaci s kalcineurinovými inhibitory nebo mykofenolátem mofetilem, tzv. kalcineurin-free režimy. Důvody pro používání mTOR inhibitorů jsou: kalcineurinová nefropatie, vaskulopatie štěpu, myopatie, cyklosporinová neurotoxicita nebo malignita [11]. Po prvním roce od transplantace se snažíme ve všech režimech vysadit kortikoidy a výsledná doživotní léčba je dvojkombinační [12].

V zásadě platí, že v rámci jedné skupiny léky nekombinujeme. Provádíme kombinaci mezi jednotlivými skupinami. Základní kombinace imunosupresiv ukazuje tab. 3 a kombinační léčbu s podáním mTOR inhibitorů tab. 4.

$U$ pacientů $v$ časnější době od transplantace srdce dáváme přednost redukovanému režimu kalcineurinového inhibitoru a mTOR inhibitoru, $v$ době déle než rok od transplantace si můžeme mezi oběma režimy vybrat. Důvodem opatrnosti v časném období v případě kalcineurin-free režimu je obava ze vzniku častějších rejekcí a hojení ran.

Kombinační imunosupresivní léčba se díky rozšíření preparátů stává pestřejší a je možno ji individuálně přizpůsobit pacientům. $V$ některých případech je výhod-

\footnotetext{
Tab. 3. Standardni kombinačni imunosupresivni léčba. Upraveno podle [13]

cyklosporin + mykofenolát mofetil + prednison (do 1 roku po transplantaci)

takrolimus + mykofenolát mofetil + prednison (do 1 roku po transplantaci)

cyklosporin + mykofenolát mofetil (více než 1 rok po transplantaci) takrolimus + mykofenolát mofetil (více než 1 rok po transplantaci)
}

\section{Tab. 4. Kombinačni imunosupresivni léčba s podánim mTOR inhibitorů. Upraveno podle [13]}

nízké dávky takrolimu + nízké dávky everolimu nízké dávky cyklosporinu + nízké dávky everolimu mykofenolát mofetil + everolimus (tzv. kalcineurin-free režim) nější používat v kombinaci cyklosporin, v jiných takrolimus a někdy přejít na režimy s everolimem (tab. 5).

\section{Komplikace po srdeční transplantaci}

časné - jsou řešeny na chirurgickém pracovišti

- poruchy funkce štěpu

- časná rejekce

- infekce

pozdní - řeší kardiolog v dlouhodobém sledování

- rejekce

- vaskulopatie štěpu

- komplikace imunosupresivní léčby (infekce, hypertenze, poruchy ledvin, neuropatie, hyperlipoproteinemie, diabetes mellitus, poruchy jater, dyspepsie, osteoporóza, útlum krvetvorby, malignity, obezita či hirsutizmus) [14]

\section{Rejekce}

Při jakékoli alotransplantaci orgánu dochází k rejekci, která představuje problém i v dnešní době při existenci řady imunosupresivních léků. Podle mechanizmu vzniku rozeznáváme rejekci celulární nebo humorální, podle rychlosti nástupu ji dělíme na hyperakutní, akutní a chronickou.

\section{Hyperakutni rejekce}

Hyperakutní rejekce se vyskytuje jen velmi zrrídka a objevuje se do 24 hod od transplantace. Jde o protilátkami zprostředkovanou rejekci, ve které hrají klíčovou roli trombózy srdečních venul, jejichž důsledkem je obstrukce drenáže transplantovaného srdce.

\section{Tab. 5. Individuálni kombinačni léčba Upraveno} podle [13]

\begin{tabular}{l|l} 
preparát & pacient s komorbiditou \\
cyklosporin & diabetes mellitus \\
\hline takrolimus & hypertenze, hyperlipoproteinemie, hyperplazie dásní \\
everolimus & $\begin{array}{l}\text { vaskulopatie, renální insuficience, malignita, } \\
\text { neuropatie }\end{array}$
\end{tabular}

\section{Tab. 6. Klasifikace rejekce podle International} Society for Heart and Lung Transplantation, původni (levý sloupec) a revize (pravý sloupec). Upraveno podle $[16,17]$

0 bez rejekce $0 \mathrm{R}$

A fokální infiltrace pyroninofilními buňkami v intersticiu $1 \mathrm{R}$ či v endokardu, bez nekrózy

1B difuzní infiltráty bez nekrózy $1 \mathrm{R}$

2 jeden fokus agresivní infiltrace, prokazatelné $1 \mathrm{R}$ myocytární léze

3A multifokální agresivní infiltráty, prokazatelné $2 \mathrm{R}$ monocytární léze

3B difuzní zánětlivý proces s nekrózou $3 \mathrm{R}$

difuzní agresivní polymorfonukleární infiltrace, $3 \mathrm{R}$ nekrózy, hemoragie 


\section{Akutni celulárni rejekce}

Akutní celulární rejekce je zprostředkována T-lymfocyty a projevuje se lymfocytární infiltrací v myokardu s pozdějším rozpadem buněk a infiltrací polymorfonukleáry.

Podle klasifikace International Society for Heart and Lung Transplantation rozeznáváme 4 stupně rejekce podle mikroskopického obrazu. V novější revizi se používá klasifikace třístupňová (tab. 6, obr. 1) [15,16].

Akutní rejekce je relativně častá potransplantační komplikace vyskytující se ve své akutní podobě především v prvých týdnech a měsících po transplantaci. Její frekvence s odstupem od transplantace obvykle klesá. Může mít dramatickou a život ohrožující podobu, nebo naopak proběhnout asymptomaticky. Před érou cyklosporinu probíhaly akutní rejekce bouřlivě, byly spojeny s EKG změnami, celkovými přiznaky, s poruchou srdeční funkce. Dnes jsou rejekční epizody většinou mírné, klinicky němé a rejekci lze prokázat pouze v bioptickém vzorku.

Neinvazivní metody mají stále ještě pomocnou cenu a nebyla dosud objevena metoda, která by nahradila

\section{Obr. 1. Akutni celulární rejekce.} Autorka MUDr. Víta Žampachová

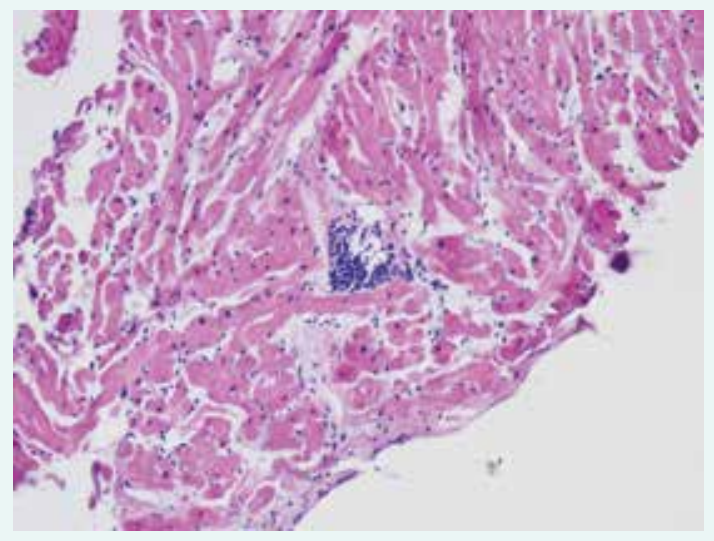

Obr. 2. Akutni humorálni rejekce. Autorka MUDr. Víta Žampachová

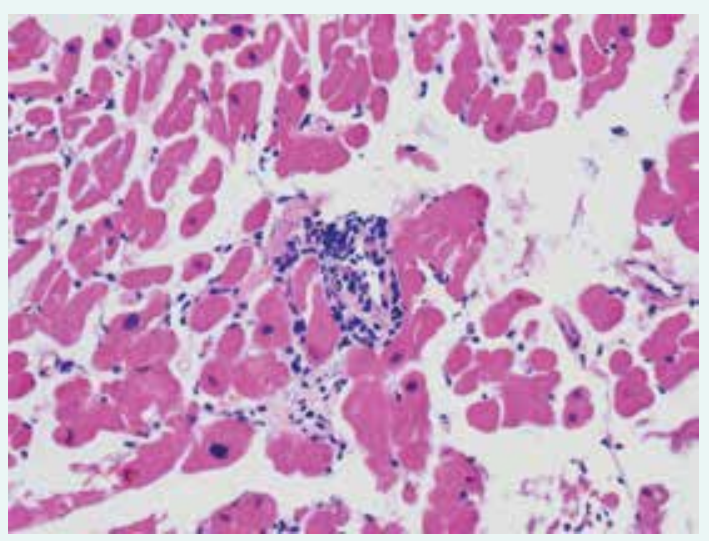

endomyokardiální biopsie v diagnostice rejekce, pokud se týče adekvátní senzitivity a specificity [12].

\section{Humorální rejekce}

Humorální neboli protilátkami způsobená rejekce je zprostředkována specifickými cytotoxickými protilátkami a je histologicky definována lineárními depozity imunoglobulinů a komplementu v myokardiálních kapilárách (obr. 2). Protilátkami způsobená rejekce se vyskytuje ve formě hyperakutní (viz výše), často provázené srdečním selháváním, a ve formě chronické, která je sdružena se sníženým dlouhodobým přežíváním, nebot' je rizikovým faktorem vývoje koronární nemoci štěpu. Metoda detekce zahrnuje barvení C4d ve tkáních, které má větší senzitivitu i specificitu než histologické charakteristiky. Humorální rejekce nereaguje na běžnou léčbu T-buňkami zprostředkované rejekce, ale může být odvrácena plazmaferézou, intravenózním podáváním imunoglobulinů, anti CD20, z nichž každý si zaslouží formální klinické zhodnocení. Jako profylaxe chronické rejekce se předpokládá v budoucnu požadavek na specifické sérologické monitorování dárce.

\section{Vaskulopatie štěpu, chronická rejekce}

Vaskulopatie štěpu je charakterizována intimálními změnami na věnčitých tepnách, označovanými také jako koronární nemoc štěpu (cardiac allograft vasculopathy (AV). Změny na koronárních tepnách se liší od klasické aterosklerózy, jde o difuzní intimální hyperplastický proces, při kterém lamina elastica interna zůstává intaktní, vzácné jsou na rozdíl od aterosklerózy kalcifikace, a na rozdíl od aterosklerózy se toto postižení vyvíjí často velmi rychle. Lumen cév se postupně uzavírá (obr. 3). Přitom na koronarogramu nemusí být tyto změny vůbec patrné, nebot' se nenajdou lokalizovaná zúžení, jedinou spolehlivou metodou $\mathrm{k}$ jejich identifikaci je pak intravaskulární ultrasonografické vyšetření (IVUS), tab. 7, [17].

Prevalence vaskulopatie je vysoká, udává se 7,8 \% první rok po srdeční transplantaci se vzrůstajícím počtem

\section{Obr. 3. Vaskulopatie štěpu.} Autorka MUDr. Víta Žampachová

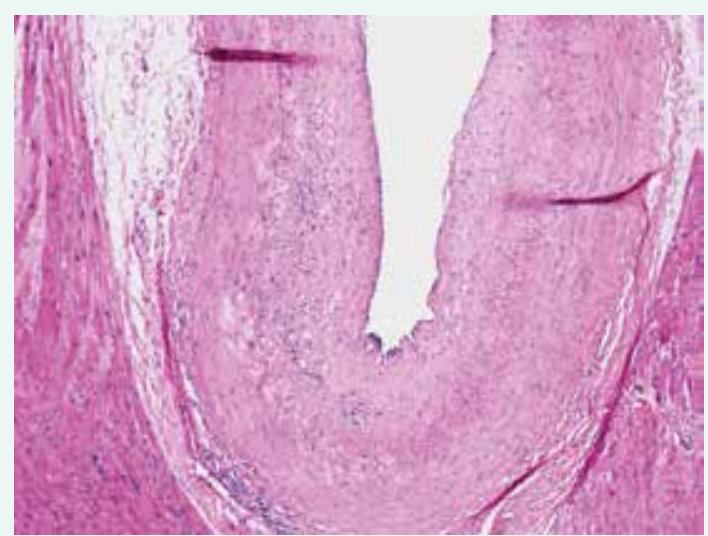


v dalších letech. Po 5 letech je již prítomna u $30 \%$ a po 10 letech u $47 \%$ pacientů [5].

Etiologie není jasná. Předpokládá se kombinace imunologického (počet rejekcí, humorální rejekce, imunokompatibilita DR systému) a neimunologického (věk a ICHS dárce, doba studené ischemie, věk, ICHS, hyperlipoproteinemie, obezita a diabetes mellitus u př́jemce) poškození endoteliálních buněk rezultujícího v myointimální proliferaci a cytomegalovirová (CMV) infekce.

Léčba je svízelná, kromě režimových opatření jako u ICHS (nekuřáctví, léčba hyperlipoproteinemie a hypertenze) se doporučuje podávání antiagregačních léků, kalciových antagonistů a inhibitorů angiotenzin-konvertujícího enzymu. Základem je podávání statinů. Pokročilá forma, která může vést až $\mathrm{k}$ dysfunkci štěpu, se reší retransplantací srdce. Řešení by do budoucna mohla přinést některá nová imunosupresiva.

\section{Komplilkace imunosuprese}

Časné infekce do 1 měsíce jsou nejčastěji nozokomiální, způsobené Pseudomonas aeruginosa, Staphylococcus aureus a některými gramnegativními kmeny.

Pozdní infekce se nejčastěji objevují mezi prvním měsícem a koncem prvního roku a jsou obecně způsobeny oportunními patogeny, jako je Cytomegalovirus (CMV), herpes viry, Pneumocystis carinii, legionella a mykózy.

Léčba spočívá v podávání antibiotik dle citlivosti, ev. antivirotik a antimykotik. Zejména pečlivě je třeba léčit prokázanou CMV virózu, protože podle některých prací může přispívat k rozvoji vaskulopatie štěpu.

Hypertenze je častou komplikací léčby cyklosporinem. Její výskyt se udává $70-90 \%$ u pacientů po srdeční transplantaci [5]. Na vzniku se podílí zvýšení tonu sympatiku, volumová expanze, zvýšená hladina endotelinu, stimulace renin-angiotenzinového systému. V dlouhodobém sledování se může uplatnit i vliv zvýšené retence dusíkatých látek. Typická je nepřítomnost nočního poklesu tlaku.

Léčba hypertenze je svízelná, ve většině případů je třeba kombinační terapie. Na prvním místě se podávají kalcioví antagonisté i pro jejich možný preventivní vliv na vznik vaskulopatie, následují inhibitory angiotenzin konvertujícího enzymu, betablokátory a diuretika $[12,18]$.

\begin{tabular}{|l|l|}
$\begin{array}{l}\text { Tab. 7. Rozdíly mezi vaskulopatii štěpu } \\
\text { a ischemickou chorobou srdeční }\end{array}$ \\
\hline $\begin{array}{l}\text { vaskulopatie } \\
\text { koncentrická difuzní prolife- } \\
\text { race intimy }\end{array}$ & asymetrické plaky \\
\hline dlouhé úseky cév & fokální léze \\
\hline $\begin{array}{l}\text { vyvijí se rychle } \\
\text { postihuje malé větve }\end{array}$ & vyvijí se pomalu \\
\hline kalcifikace zřídka & postihuje více proximální úseky \\
\hline kolaterály zř́dka & kalcifikace často \\
\hline
\end{tabular}

Nefropatie souvisí s podáváním inhibitorů kalcineurinu: cyklosporinu nebo takrolimu. U pacientů, kteří mají kalcineurinovou nefropatii, Ize zvážit převedení na everolimus a nízké dávky cyklosporinu či takrolimu, ev. na kalcineurin-free režimy [19]. Je však třeba pečlivě sledovat pacienta, aby na druhé straně nedošlo k poddávkování pacienta a vzniku rejekce.

Hyperlipoproteinemie se popisuje u 60-80 \% pacientů po srdeční transplantaci. Hladiny cholesterolu se zvyšují někdy již v prvních 3 týdnech a nejčastěji k tomu dochází v průběhu prvních 6-18 měsíců. V léčbě se uplatňuje dieta, redukce kortikoidů a podávání statinů [12]. Zde je třeba dávat pozor na možné interakce s cyklosporinem a raději používat ty statiny, které využívají jiných metabolických cest, jako je pravastatin nebo fluvastatin [20]. Výhodná je kombinace takrolimu s atorvastatinem, u níž je vznik interakcí minimální [21]. Nově se nyní podává v redukované dávce i rosuvastatin.

Diabetes mellitus souvisí s podáváním kortikoidů. Zhoršování diabetu také podporuje takrolimus. Je třeba sledovat hladiny glykemie a v případě nového vzniku diabetu začít s dietní a farmakologickou léčbou. U pacientů, kteří již diabetes měli, se často přechází na inzulin, či jsou jeho dávky zvyšovány. Jako výhodné se jeví podávání metforminu, při jehož podávání byl u pacientů po ortotopické transplantaci srdce prokázán i snížený výskyt malignit [24]. Je snaha o udržení euglykemie vzhledem k prevenci vývoje vaskulopatie štěpu $[12,23]$.

Metabolický syndrom. Výskyt metabolického syndromu byl sledován u pacientů v epidemiologické studii TRACA (TRAnsplant CArdiaco). Prevalence metabolického syndromu byla $42 \%$ a byla častější u pacientů, jejichž diagnóza pro transplantaci srdce byla ischemická choroba srdeční oproti jiným diagnózám (52 vs $27 \%$ ) [24]. V našem vlastním souboru pacientů mělo současnou hyperlipoproteinemii a diabetes mellitus 165 pacientů, tj. 52 \% [25].

Pokud má pacient metabolický syndrom již před transplantací, je to další rizikový faktor dlouhodobého přežívání. Pacienti s metabolickým syndromem, diagnostikovaným před či po transplantaci srdce, mají také častěji vaskulopatii štěpu [26].

\section{Tab. 8. Př́činy úmrtí po transplantaci srdce.} Upraveno podle [5]

\begin{tabular}{|l|l|}
\hline první měsíc & selhání štěpu $40,5 \%$ \\
\hline & multiorgánové selhání 17,6\% \\
\hline infekce $14,0 \%$ \\
\hline infekce $31,6 \%$ \\
\hline od 30 dnů do roku & selhání štěpu $17,8 \%$ \\
\hline multiorgánové selhání 15,8\% \\
\hline rejekce $8,7 \%$ \\
\hline od 5 let & vaskulopatie 32,3\% \\
\hline malignity $21,6 \%$ \\
infekce $10,7 \%$
\end{tabular}


Jaterní poruchy mohou vznikat v souvislosti s podáváním cyklosporinu a jsou závislé na dávce. Je rovněž ovlivněn metabolizmus bilirubinu, může docházet k cholestáze a tvorbě žlučových kamenů.

Z gastrointestinálních potíží je častá dyspepsie, kortikoidy mohou aktivovat nebo vést $k$ vředové chorobě.

Osteoporóza. Hlavním faktorem přispívajícím k jejímu vzniku je podávání kortikoidů a ledvinná nedostatečnost (pokud je prítomna). Výskyt roste se stoupajícím věkem a u žen po menopauze. Léčba spočívá opět ve vysazení kortikoidů, podání vápníku, kalcitoninu, vitaminu $\mathrm{D}$ a rehabilitaci.

Poruchy krvetvorby, zvláště pokles bílých a následně i červených krvinek, může způsobit zejména mykofenolát mofetil. Léčba spočívá v jeho vysazení a nasazení jiného imunosupresiva, podání prednisonu, při těžších útlumech krevní převody ev. růstové faktory.

Malignity. Pacienti po transplantaci mají mnohonásobně větší riziko vzniku maligních onemocnění než jejich stejně staří vrstevníci [27]. Nejčastějším prípadem jsou kožní malignity a dále abnormální proliferace B-lymfocytů. Udává se, že vznik lymfomů může být indukován EB virem.

V australské studii [28] bylo srovnáno 907 pacientů po transplantaci srdce, srdce a plic či plic s incidencí malignit $u$ věkově srovnatelné populace bez orgánové transplantace. $V$ souboru pacientů po transplantaci bylo 424 úmrtí, bylo potvrzeno 102 onkologických onemocnění, což představovalo 7,1krát vyšší incidenci ve srovnání s běžnou populací. Nejčastější malignitou bylo lymfoproliferativní onemocnění (692/100 000 osob za rok), dále malignity hlavy a krku (336/100 000 osob za rok) a rakovina plic (251/100 000 osob za rok). Prri srovnání s běžnou populací je riziko zvýšeno u jednotlivých malignit 26,2násobně, 21,0násobně a 9,3násobně [28].

\section{Přeživání pacientů}

Jednoleté přeživání pacientů po srdeční transplantaci je u pacientů s primární diagnózou dilatační kardiomyopatie $84 \%$, u ischemiků je $81,5 \%$ a u pacientů se srdeční vadou $77 \%$. Pětileté přežívání je $71 \%$ a desetileté 56 \% [5]. Příciny úmrtí po transplantaci srdce ukazuje tab. 8 [5].

Přičiny úmrtí, které odrážejí výsledky nadměrné imunosuprese (infekce a malignity), jsou v rovnováze s příčinami podsuprimování (vaskulopatie štěpu či jeho selhání).

\section{Závěr}

Srdeční transplantace se $v$ posledních 3 desetiletích stala zavedenou metodou léčby těžkého srdečního seIhání. Přes mnohá úskalí prodlužuje nemocným život a zlepšuje jeho kvalitu. I v budoucnosti si jistě zachová své místo. Je však možné, že se vyvinou i další postupy, které by mohly sloužit jako její alternativa.

\section{Literatura}

1. Barnard CN. A human cardiac transplant. S Afr Med J 1967; 41(48): 1271-1274.
2. Černý J. Historie srdečních transplantací - krátké zamyšlení. Vnitř Lék 2000; 46(11): 741-742.

3. Hosain N, Amin F, Leprince P. Christian Cabrol MD: A Tribute to pioneer cardiac surgeon Christian Cabrol 1 year after his death, on the 50th Anniversary of the First European Human Heart Transplantation that he performed in 1968. Eur Heart J 2018; 39(19): 1661-1671. Dostupné z DOI: <http://dx.doi.org/10.1093/eurheartj/ehy195>.

4. Fabián J. Z historie slovenskej transplantológie srdca. Cardiol 2000; 9(4): 200-201.

5. Lund LH, Khush KK, Cherikh WS et al. The Registry of the International Society for Heart and Lung Transplantation. Tirty-fourth Adult Heart Transplantation Report-2017; Focus Teme: Allograft ischemic time. J Heart Lung Transplant 2017; 36(10): 1037-1046. Dostupné z DOI: <http://dx.doi.org/10.1016/j.healun.2017.07.019>.

6. Kočandrle V, Fabián J, Firt P. Transplantace srdce. Čas Lék čes 1984; 123(47): 1425-1429.

7. Ponikowski P, Voors AA, Anker SD. et al. 2016 ESC Guidelines for the diagnosis and treatment of acute and chronic heart failure The Task Force for the diagnosis and treatment of acute and chronic heart failure of the European Society of Cardiology (ESC). Developed with the special contribution of the Heart Failure Association (HFA) of the ESC. Eur Heart J 2016; 37(27): 2129-2200. Dostupné z DOI: <http://dx.doi. org/10.1093/eurheartj/ehw128>.

8. Špinar J, Hradec J, Špinarová L et al. Souhrn doporučených postupů ESC pro diagnózu a léčbu akutního a chronického srdečního seIhání z roku 2016. Připraven Českou kardiologickou společností. Cor Vasa 2016; 58(5): 455-494.

9. Crespo-Leiro MG, Metra M, Lund LH et al. Advanced heart failure: A position statement of the Heart Failure Association of the European Society of Cardiology. Eur J Heart Fail 2018. Dostupné z DOI: <http:// dx.doi.org/10.1002/ejhf.1236>.

10. Ammirati E, Oliva F, Cannata A et al. Current indication for heart transplantation and left ventricular asisst device: a practical point of view. Eur J Int Med 2014; 25(5): 422-429. Dostupné z DOI: <http:// dx.doi.org/10.1016/j.ejim.2014.02.006>.

11. Rothenburger M, Zuckermann A, Bara $C$ et al. Recommendations for the use of everolimus (Certican) in heart transplantation: results from the second German-Austrian Certican Conference. J Heart and Lung Transpl 2007; 26(4): 305-311. Dostupné z DOI: <http://dx.doi.org/10.1016/j.healun.2007.01.010>.

12. Costanzo MR, Dipchand A, Starling $R$ et al. The International Society of Heart and Lung Transplantation Guidelines for the care of heart transplant recipients. J Heart Lung Transplant 2010; 29(8): 914-956. Dostupné z DOI: <http://dx.doi.org/10.1016/j.healun.2010.05.034>.

13. Špinarová $L$, Vítovec J. Kombinační imunosupresivní léčba. Kardiol Rev a Int Med 2014; 16(6): 472-474.

14. Špinarová L. Transplantace srdce - minulost, současnost a výhled do budoucna. Vnitř Lék 2010; 56(8): 884-888.

15. Billingham ME, Cary NR, Hammond ME et al. A working formulation for the standardization of nomenclature in the diagnosis of heart and lung rejection. Heart rejection Study Group. The International Society for Heart and Lung Transplantation. J Heart Transplant 1990; 9(6): 587-593.

16. Stewart S, Winter GL, Fischbein MC et al. Revision of the 1990 Working Formulation for the standardization of nomenclature in the Diagnosis of Heart rejection. J Heart Lung Transplant 2005; 24(11): 1710-1720. Dostupné z DOI: <http://dx.doi.org/10.1016/j. healun.2005.03.019>.

17. Špinarová L. Sledování pacienta po transplantaci srdce. In: Táborský M, Kautzner J, Linhart A. Kardiologie. 2. ed. Mladá fronta: Praha 2018: 1382-1390. ISBN 978-80-204-4812-5. ISBN 978-80-204-48132. ISBN 978-80-204-4900-9.

18. Špinarová $L$, Hude $P$, Krejčí J et al. Farmakoterapie hypertenze po transplantaci srdce. Vnitř Lék 2012; 58(7-8): 608-611.

19. Rothenburger M, Zuckermann A, Bara $C$ et al. Recommendations for the use of everolimus (Certican) in heart transplantation: results from the second German-Austrian Certican Conference. J Heart and Lung Transplant 2007; 26(4): 305-311. Dostupné z DOI: <http://dx.doi. org/10.1016/j.healun.2007.01.010>. 
20. Špinarová L, Vítovec J. Statiny a srdeční transplantace. Remedia 2005; 15(2): 154-157.

21. Skalická B, Kubánek M, Málek I et al. Conversion to tacrolimus and atorvastatin in cyclosporine- treated heart transplant recipients with dyslipidemia refractory to fluvastatin. J Heart Lung Transplant 2009; 28(6): 598-604. Dostupné z DOI: <http://dx.doi.org/10.1016/j. healun.2009.03.014>.

22. Peled Y, Lavee J, Raichlin E et al. Metformin therapy reduces the risk of malignancy after heart transplantation. J Heart Lung Transplant 2017; 36(12): 1350-1357. Dostupné z DOI: <http://dx.doi.org/10.1016/j. healun.2017.06.009>.

23. Nikolaidis L, Shah S, McGonagle F et al. Diabetes mellitus following heart transplantation. J Heart Lung Transplant 2010; 29(2 Suppl): S154. Dostupné z DOI: <https://doi.org/10.1016/j.healun.2009.11.485>.

24. Fort AC, Gavira JJ, Alegria-Barrero E et al. Prevalence of metabolic syndrome in heart transplant patients: Role of previous cardiopathy and years since the procedure - the TRACA study. J Heart Lung Transplant 2006; 25(10): 1192-1198. Dostupné z DOI: <http://dx.doi.org/10.1016/j.healun.2006.06.012>.

25. Špinarová L, Lidinský P, Krejčí J et al. Metabolický profil pacienta po transplantaci srdce. Cor Vasa 2013; 55(4): 423-427.
26. Sanchez-Lazaro I, Sanchez-Gomez JM, Martinez-Dolz L et al. Is metabolic syndrome important in the development of cardiac allograft vasculopathy in heart transplantation patients? J Heart Lung Transplant 2012; 31(4 Suppl): S94. Dostupné z DOI: <https://doi.org/10.1016/j.healun.2012.01.267>.

27. Špinarová L, Hude $P$, Krejčí J et al. Osud pacientů přežívajících deset let po transplantaci srdce se zřetelem $\mathrm{k}$ výskytu maligního onemocnění. Cor Vasa 2009; 51(6): 415-418.

28. Roithmaier S, Haydon AM, Loi S et al. Incidence of malignancies in heart and/or lung transplant recipients: a single-institution experience. J Heart Lung Transplant 2007; 26(8): 845-849. Dostupné z DOI: $<$ http://dx.doi.org/10.1016/j.healun.2007.05.019>.

\section{prof. MUDr. Lenka Špinarová, Ph.D. $\triangle$ lenka.spinarova@fnusa.cz}

I. interní kardio-angiologická klinika LF MU a FN u sv. Anny $v$ Brně

www.fnusa.cz

Doručeno do redakce 18. 7. 2018

Prijato po recenzi 13. 8. 2018 